\title{
Sustainable Development Policy: A Participatory Approach to Increase Students' Awareness of Solid Waste Management
}

\author{
By Zeinab Shawky Younis ${ }^{1}$, Ola Mamdouh ${ }^{2}$
}

\begin{abstract}
Sustainability entails a development that meets the present generation's needs without compromising the ability of future generations to meet their own needs (Brundtland Commission, 1987). Hence, new public management practices need to be restored sustainably to fulfill the social contract theory by protecting citizens' happiness, security, and development. Sustainable development goals (SDGs) in this direction mobilize many specialized fields, including public administration in its new form. New public management (NPM) practices are the art of maximizing value from natural resources and human capital. In designing organizations for such a citizen-enabled strategy within NPM in a sustainable perspective, policymakers must identify stakeholders, commitment of the initiators, and the innovation pattern in introducing this policy to the environment (Kairouz, 2016). This research paper introduces an attempt to set a sustainable development policy to maintain solid waste management (SWM) from administrative and a citizen-oriented reform policy orientation. In Egypt, SWM is a persistent issue reflecting on the environment; hence, social and health problems must be properly managed through developmental policies to contribute to the country's welfare. The policy instrument of NPM in SDGs entails both municipal waste management and the rationalization of fossil fuel subsidies. The research conducted a pilot study of three months using sustainable supply chain management practices as a tool for managing solid wastes in universities where wastes are considered a product, which requires management throughout this chain to maximize efficiency and sustain the environment. The business model includes suppliers of the waste, including any firm that supplies the university with material for the ongoing study period. It also includes any individual bringing goods of usage in the campus that turn into waste. The referential analysis technique is used to draw a generalization of conclusions depending on the logic found in areas of secondary sources in early studies.
\end{abstract}

Keywords: New public management; Sustainable development goals; Solid waste management; Sustainable supply chain management; Citizen-enabled strategy; The British University in Egypt

\section{Introduction}

According to John Maxwell, "we tend to get in life what we are willing to tolerate." Here, sustainability helps us tolerate our environment in harmony and agility to embrace the change, and then we work on sustaining it through different policies. These, in turn, help us formalize the change into rules and regulations to create a clean, healthy environment and a more citizen-centered sustainable public management. This depends on objectives to maximize the value drawn from available resources.

The need for sustainable development policies to work for the future generations falls

| ${ }^{1}$ Associate Professor Public Administration, Business Administration Department, the British University in

${ }^{2}$ Lecturer, Operations Management, Business Administration Department, the British University in Egypt 
under the umbrella of two concepts. One is the need to create a better life in a challenging future of societies and industries. The other is the idea of the limitation imposed by the agility of the strategy used, the innovative tools, and the vision behind introducing the change needed to embrace development. To run the process efficiently, institutions must foster innovation to sustain the construct of practices involved toward a sustainable solid waste management (SWM) policy (Peculea, 2019). Innovation weakens rigid structures, enhances agility and technology-enabled learning, presents a guarantee to financial resource depletion, and provides insightfulness outside the box of action for more creativity. The participatory approach of university involvement used in this research will enable students to change their mindset toward a more citizen-oriented responsible behavior. The flow of information disseminated through formal and informal channels of communication to students must be administered to ensure high commitment and involvement. This can be done through various training workshops through a wide coordination between research and institutions in practicing SWM.

The administrative reform suggested in this study will arise from an understanding of the importance of sustainable SWM to create a healthy environment that solves air and water pollution. The choice of higher education institutions as universities is crucial to the study as it has a multiplier effect and a vital role in students' life to increase their awareness of their environment. It is also vital in teaching and learning research and in the supply of available materials as they generate wastes during their daily activities. According to the sustainable development strategy, that is, Egypt vision 2030, Egypt is entailed for a systematic development to reach a highly competitive, stable, and diversified economic development by 2030. This is based on equality, social inclusion, and participation of all stakeholders in society to preserve an ecologically safe environment. The Ministry of Planning and the Institute of National Planning started in January 2018 to update sustainable development policies and ensure the alignment of the 2030 strategy with sustainable development goals (SDGs) proposed by the United Nations and the African Agenda of 2063. Their operation stems from evaluating the public management practices in place since 2016 onward. In this agenda, SWM is the top priority, which leads us to question whether sustainable development policy is a reality performed.

\section{Literature Review}

\subsection{The Role of Public Administration in the Sustainable Development Goals 2.1.1 Public Administration}

By mere definition, Public administration, with its policies for development and rendering services, is inclined toward a broad sense of security, environmental planning, citizenship orientation, and basic human rights. The SDGs proved a strong vision aligning with the priority setting of the nation's requirements and national policy cycles and citizenship orientation. According to the International Institute of Administrative Sciences (2008), public administration's policy instruments rely on the first responsibility of public governance in providing techniques for municipal waste management and rationalizing fossil fuel subsidies. These policies function in great strengths under the basic assumptions of new public management (NPM), including the description of a business environment focusing on stakeholders, citizens, and customers, and the need for performance 
management and measurement systems (Diefenbach, 2009).

\subsection{SWM System and Sustainable Development Policies}

The SWM system has multiple impacts on the three dimensions of sustainable development: environmental, economic, and social. In the environmental dimension, improper management of the generated solid waste causes a considerable burden on the environment in terms of air, land, and water pollution. In the economic dimension, collaborations in handling the project on the floor of the BUE will generate revenue and produce sustainable job market opportunities. Furthermore, in the social dimension, the students' participation will transcend the project's impact to apply it outside university borders in the future in different municipalities and gain the support of various stakeholders. The BUE will build its reputation as a role model to other academic institutions to apply the sustainable supply chain management (SSCM) as a tool to manage its solid wastes.

\subsection{Supply Chain and SWM}

This study proposes that the SWM problem is tackled from a supply chain perspective. It draws a strategy in SWM in the British University in Egypt that uses the SSCM practices as a tool. Moreover, it considers the waste generated by the university as a product. The supply chain of this product (waste) requires to be managed efficiently and sustainably. Solid waste is defined by the Organization for Economic Co-operation and Development (OECD, 2003) as a useless and often dangerous material that presents low liquid content. The current consumption model ("disposable mentality" and "throwaway culture") is accused of a crisis in the field of waste production and failure in the policies of managing waste globally (O’Brien, 2013). Thereby, the researchers believe that applying SSCM as a tool in managing solid wastes would aid in achieving the 12th SDG concerned with responsible production and consumption.

Supply chain management is the coordination of the sequence of organizations and their functions that are involved in the production and delivery of a product or a service. The sequence begins with primary suppliers of raw materials and extends to the final customer. The supply chain of the waste produced in the university could be explained in terms of suppliers, internal operations within the campus, and customers. The suppliers, in this case, comprise two types. The first type is any firm that supplies and provides the university with materials for the ongoing operation of the university. These materials are used for their designated purpose and are then transferred to the thrown away waste. The second type is any individual arriving on campus, bringing goods for usage that might result in a waste he or she might need to discard. These two types of suppliers are considered to be delivering raw materials, which enter the production line (university campus), to be used and then transferred into waste. Currently, the customers of this product (waste) are waste collectors. This current linear solid waste chain results from the disposable mentality that O'Brein (2013) discussed. Adopting the SSCM practices tool for managing solid waste in the university will add other customers too, such as different recycling factories for different types of waste. Thereby, the linear supply chain of solid wastes in the university could be transferred to a circular sustainable chain.

According to Ahi and Searcy (2013), a sustainable supply chain is considered an extension 
to the green supply chain whose main concern is on environmental aspects in addition to the social and resilient supply chain practices. Meanwhile, Zhu, Sarkis, and Lai (2008) mentioned that the green supply chain management is composed of practices revolving green purchasing to integrate life-cycle management supply chains flowing from the supplier, to manufacturer, customer, and closing the loop with reverse logistics. The steps of achieving the social aspect of the project are reflected by educating and teaching students about the sustainability of the university campus and how that can be accomplished by SWM as a means and embedding it in their curricular and extra-curricular activities to ensure their participation.

Based on this project, this study focuses on specific SSCM practices that are believed to have the most significant impact on managing solid waste in the university. This study mainly focuses on the following practices: internal environmental management, ecodesign, and environmental customer cooperation.

The following is a brief description of each practice and how it can be applied to SWM.

\subsubsection{Internal Environmental Management}

For any change to occur in a company, it requires direly senior managers' blessings in terms of support and commitment (Hamel, Doz \& Parahalad, 1989; Zhu \& Sarkis, 2004). The application of sustainable development policy in SWM stems from the urgency of creating competitive internal environmental management able to capitalize on new innovations and acting toward a flawless modification of the way these wastes were previously handled. Agility is a tool for continuing growth and adaptation in times of disruptions where short-term goals are aligned into broader perspectives in accepting change embedded in society. The administration of the university program for SWM, the middle managers, the students, and all staff members involved from top management to the lowest-ranking worker in the chain of command must be agile enough to embrace the program. The environmental management system is a database system, which integrates procedures and processes for training of personnel, monitoring, summarizing, and reporting specialized environmental performance information to the institution's internal and external stakeholders (Sroufe, 2003).

Meanwhile, the business administration department is a signatory with the Principles for Responsible Management Education (PRME), and the university can take this further by applying an environmental management policy. The department is now undergoing the agile transformation to apply these principles that give an ample opportunity to run the policy within this umbrella. The inclination here is to change educational programs to implement a learning mindset recognizing opportunities and reacting to changing technologies to mobilize resources and enhance the understanding of the education purpose over profits to engage the community with mutual benefits. This aligns with the first UN principle of the PRME where it aims to pave the way for more students' engagement to be "future generators for sustainable value for business and society" (principle 1 available at www.unprme.org). It is also parallel to the second principle, where any curriculum must include activities that reflect CSR to involve community work and services as the United Nations Global Compact portrays. Therefore, having an environmental management policy in place would aid the process of managing solid wastes in the university sustainably. 


\subsubsection{Eco-Design}

Norton (2012) stated that eco-design is based on rethinking the product and its functions from first principles to minimize environmental and resource impacts. This can be achieved, for example, by using recycled materials, designing to re-use all or part of the product, designing products that are easy to repair, reducing resource consumption across the life cycle, and replacing hazardous substances with non-hazardous alternatives.

The university could embed eco-design practices that would minimize the environmental impact associated with SWM service. The segregation of waste at source falls under the eco-design of the SWM service. The infrastructure for this has been embedded within the faculty by providing green bins for used paper separation. Other steps would follow for other bins and types of waste separation. A campaign for paper recycling has been introduced within the faculty, targeting staff and students. Five green bins have been placed in the areas with high traffic. Other tasks, such as shifting to a paperless system to reduce the consumption of paper, are another eco-design task that was in place. Coursework shifting to paperless has already saved the use of papers.

\subsubsection{Environmental Customer Cooperation}

Lai, Wong and Lam (2015) stated that environmental customer cooperation involves sharing strategic information and collaboration between a company and its customers. This improves visibility and enables joint planning for the environment (cited in Geng, Mansouri \& Aktas, 2017).

In this research project, the students and staff regarded as customers whose environmental cooperation is needed while producing waste within the campus. They are targeted to sort it when removing waste. Other customers are the companies that purchase the segregated waste that sells it further to recycling factories across the waste supply chain. The research project conducted several activities under the environmental customer cooperation practices associated with SWM. Among which is to ally with recycling factories (plastic, paper, cardboard, and electronic wastes). Moreover, the university could ally with firms and SMEs to link waste generator institutions and recycling factories.

Customer cooperation for the green supply chain management is a process perspective, which tackles customer relationships that occur within the chain and at several levels. The issue arising here is the degree of customer cooperation and readiness to level up to the society's expectations and initiatives. What has been achieved on the BUE campus and was measured by the survey included in the study is an example of local development collaboration to enhance social and environmental management on campus, thereby increasing awareness among students and staff members of the Business Administration, Economics and Political Science (BAEPS) faculty.

The key to this is culture, which plays a key factor in this sense via the community's involvement through well-designed educational programs promoting sustainability and recycling patterns. Several sessions from an Egyptian recycling company for SWM, the socalled "Go-Green," were provided simultaneously, targeting the students and staff members of the Faculty of BAEPS that is a signatory in the field of responsible management this 2020 academic year and luckily enough before the start of the first wave of COVID-19. Several awareness messages were tackled through the workshops conducted to reach an adequate degree of transferable knowledge about the importance 
of the issue among students and staff. The Research Center for Innovation, Governance and Green Economy (CIGGE), in collaboration with the BAEPS faculty, conducted these sessions and tackled different Question \& Answers "Did u know?" scenarios around facts of SWM recycling.

To ensure customer cooperation, the CIGGE, in collaboration with the community services committee at the faculty of BAEPS, launched a "Paper-recycling campaign." Its aim was to cut down paper waste and encourage paper recycling. The Center encouraged students who have an artistic talent to design a logo and a slogan for the campaign as a part of a pilot study at the level of faculty research and innovation. The three best logos were chosen by the jury from the Center and the marketing specialization of the faculty of BAEPS. In addition, sustainability awareness sessions were conducted for students and staff and primarily focused on waste management.

By reflecting the model of Bennett and Nunes (2008) in line with customer cooperation on the SWM project in BUE, we had to run an environmental SWOT analysis to scan threats and opportunities. We discovered the following results:

1- A regulation procedure and cultural new scheme to face the threat in accepting change: This was faced through an organized lecture at the business department in February 2020 under the topic of "How enterprises make an unavoidable impact on the environment and how vital it is to reduce it."

2- Conduct a customer value feasibility and cost-benefit relationship to establish, implement, and monitor practices: This was done through a series of social supply chain practices.

\section{Methodology}

The researchers used simple regression to test the effect of the different constructs (i.e., recycling skill, availability of infrastructure, perceived costs and benefits, awareness of consequence, and the perception of waste pickers) on the waste-sorting behavior and intention. This methodology explores the extent of environmental customer cooperation. The subjects in this research are the students and staff of BAEPS (research population). The research sample is composed of 100 respondents as a preliminary pilot study. The survey was administered online by survey monkey software. Moreover, the researchers used the questionnaire of Fan, Yang, and Shen (2018) to explore the solid waste-sorting behavior of the research population. The questionnaire included statements to measure the research variables on a 5 -point Likert scale. Table 1 briefly explains the relevant research variables.

Table 1: Relevant variables tested within the hypotheses

\begin{tabular}{ll}
\hline Variables & Brief Definition \\
\hline $\begin{array}{l}\text { Waste-sorting Behavior } \\
\text { (Dependent) }\end{array}$ & $\begin{array}{l}\text { A kind of pre-environmental behavior impacted by both factors of motivation } \\
\text { and contextual environment (Stern, 1999). There are various elements for the } \\
\text { behavior of waste separation. }\end{array}$ \\
$\begin{array}{l}\text { Waste-sorting Intention } \\
\text { Environmental behavior interventions can occur to influence waste-sorting }\end{array}$ \\
$\begin{array}{l}\text { Eecycling Skill } \\
\text { intention, which in turn influences waste-sorting behavior (Fan et al., 2018). } \\
\text { (Independent) }\end{array}$ & $\begin{array}{l}\text { Numerous research highlighted the positive effect of recycling skill and knowledge } \\
\text { on the behavior of waste separation (Ramayah et al., 2012; Fan et al., 2018). }\end{array}$ \\
\hline
\end{tabular}




\begin{tabular}{|c|c|}
\hline Variables & Brief Definition \\
\hline Perceived Benefits and & Perceived costs and benefits have strong impact to increase waste separation \\
\hline Costs (Independent) & behavior and intention (Ølander and Thøgersen, 1995; Fan et al. (2018). \\
\hline Awareness of & It implies the person's perception and understanding of the disadvantages for \\
\hline Consequence & valued objects when not performing pro-environmental behavior (Stern, 1999; \\
\hline (Independent) & Fan et al., 2018). \\
\hline Perception of Waste & The perception of waste pickers is considered a motivation for waste-sorting \\
\hline Pickers (Independent) & behavior. Previous research identified that the behavior of waste pickers is \\
\hline & $\begin{array}{l}\text { informal so this discourages the individuals who might have intentions to } \\
\text { separate waste (Wang, 2001; Fan et al., 2018). }\end{array}$ \\
\hline Availability of & Ample studies have found that enhancing of infrastructure in terms of number \\
\hline Infrastructure & and location of waste bins (Tonget, 2004; Fan et al., 2018), encourage citizens to \\
\hline (Independent) & ental friendly. \\
\hline
\end{tabular}

Given the previous literature on the different research variables, the following hypotheses were developed. Responses were collected from a sample of students and staff to test them:

H1: Recycling skill has a positive significant impact on waste-sorting behavior of individuals.

H2: Strong infrastructure has a positive significant impact on waste-sorting behavior of individuals.

H3: Perceived costs and benefits has a positive significant impact on behavioral intention for waste-sorting. H4: Awareness of consequence has a positive significant impact on behavioral intention for waste-sorting. H5: Perception of waste pickers has a negative significant impact on behavioral intention for waste-sorting.

\subsection{Reliability}

The questionnaire constructs' reliability has been measured by calculating the Cronbach's alpha to measure the internal consistency. It all yielded high values, showing how closely related the statements are as a group under each construct. Table 2 shows the reliability of the constructs.

Table 2: Cronbach's alpha values for the questionnaire constructs

\begin{tabular}{lcc}
\hline Construct & Cronbach's alpha & No. of items \\
\hline Waste-sorting Behavior & 0.855 & 6 \\
Waste-sorting Intention & 0.904 & 5 \\
Recycling Skill & 0.790 & 5 \\
Infrastructure & 0.746 & 4 \\
Perceived Cost and Benefit & 0.030 & 3 \\
Awareness of Consequence & 0.806 & 4 \\
Subjective Norm & 0.865 & 4 \\
Perception of Waste Pickers & 0.482 & 3 \\
Response Efficacy & 0.919 & 3 \\
\hline
\end{tabular}

\section{Research Findings}

The survey administered to explore the environmental customer cooperation has led to the following findings and hypothesis testing.

\subsection{Waste-Sorting Behavior (Dependent Variable)}

The mean for the waste-sorting behavior statements is 2.89 . The direction of this 
construct is neutral to disagree. This could be interpreted to mean that $27 \%$ of the respondents have agreed to the sorting out of water plastic bottles, newspapers, magazines, and cardboard boxes at home. Meanwhile, $36 \%-24 \%$ of the respondents have disagreed with the other statements about sorting out other plastic waste, metal waste, kitchen garbage, and toxic substances.

\subsection{Waste-Sorting Intention (Dependent Variable)}

The mean for the waste-sorting intention is 4.19. The direction of this construct is toward agreeing to the statement. This demonstrates that $43 \%-51 \%$ of the respondents (majority) either agree or completely agree to the statements about their intentions to sort waste if available in their community.

\subsection{Recycling Skills (Independent Variable)}

The mean for the recycling skill is 2.95 , demonstrating a direction toward the disagreement to the statements. This is proved by only the $30 \%$ (minority) of the respondents who agree to knowing the recyclable plastic types, whereas $31 \%-32 \%$ (majority) are either neutral or disagree to knowing which waste is recyclable and how the recyclables are sorted.

\subsection{Availability of Infrastructure (Independent Variable)}

The mean of the availability of the infrastructure is 2.79 , demonstrating a direction toward the disagreement to the statements. This is proved by $26 \%-40 \%$ of respondents who chose Neutral or Not Applicable to the statements. This could be interpreted that no infrastructure is available in terms of litter bins for recycling, management and wellmarking of the recycling bins, and guidance in waste-sorting.

\subsection{Perception of Waste Pickers (Independent Variable)}

The mean of the perception of waste pickers is 3.16, showing a direction more toward the agreement to the statements. This is proved by the $32 \%-46 \%$ of respondents who agree to the statements that waste pickers will always litter the sorted recyclables and will get rid of the recyclables that they do not want.

\subsection{Perceived Costs/Benefits and Awareness of the Consequence (Independent Variable)}

The mean of the perceived costs and benefits is 2.82 , indicating a direction toward the disagreement to the statements. Between $41 \%$ and $44 \%$ of the respondents disagree that they will recycle only if they receive cash or profits by recycling or pay some penalty for not recycling. This finding may relate to the "awareness of the consequence" construct, where the mean for these statements is 4.36 , showing a direction toward the agreement. It can be deduced that the respondents are aware of the consequences of not recycling. Therefore, they are willing to recycle regardless of profits or penalties associated with the process. Between $47 \%$ and $59 \%$ of the respondents are aware or completely aware of the consequences of not recycling. After extending the study and expanding the sample, researchers determined that the more the respondents know the consequences of not recycling, the more they will recycle without gaining a benefit or paying a penalty for not 
recycling.

\subsection{Hypotheses Testing}

\subsubsection{H1: Recycling skill has a positive significant impact on waste-sorting behavior of individuals.}

Table 3: Regression Model Output for H1

\begin{tabular}{|c|c|c|c|c|c|}
\hline Model Summary & & & & ANO & $\overline{V^{a}}$ \\
\hline Model & $\mathrm{R}$ & $\mathrm{R}^{2}$ & Adjusted $\mathrm{R}^{2}$ & $\mathrm{~F}$ & Sig. \\
\hline $\begin{array}{l}\text { a. Predictors: (Constant), Recycling skill } \\
\text { Coefficients }^{\mathrm{a}}\end{array}$ & $.312^{\mathrm{a}}$ & .098 & .088 & 10.599 & $.002^{\mathrm{b}}$ \\
\hline a. Dependent Variable: the waste-sorting & havior & $\begin{array}{c}\text { Unstandardized } \\
\text { Coefficients } \\
\text { B }\end{array}$ & $\begin{array}{c}\text { Standardized } \\
\text { Coefficients } \\
\text { Beta }\end{array}$ & $\mathrm{t}$ & Sig. \\
\hline 1 & $\begin{array}{l}\text { (Constant) } \\
\text { Recycling skill }\end{array}$ & $\begin{array}{c}1.789 \\
.374\end{array}$ & .312 & $\begin{array}{l}5.067 \\
3.256\end{array}$ & $\begin{array}{l}.000 \\
.002\end{array}$ \\
\hline
\end{tabular}

The model (Table 3) shows a significant positive relationship at 0.02 between recycling skill and waste-sorting behavior. Every change by 100\% in recycling skill will lead to a change in waste-sorting behavior by $37.4 \%$. Moreover, $\mathrm{R}^{2}(0.098)$ shows that recycling skill explains $9.8 \%$ of the waste-sorting behavior. Therefore, $\mathrm{H} 1$ is not rejected.

\subsubsection{H2: Strong infrastructure has a positive significant impact on waste-sorting behavior of individuals}

Table 4: Regression Model Output for H2

\begin{tabular}{|c|c|c|c|c|c|c|}
\hline \multicolumn{4}{|l|}{ Model Summary } & \multicolumn{3}{|c|}{ ANOVAa $^{a}$} \\
\hline Model & $\mathrm{R}$ & $\mathrm{R}^{2}$ & $\begin{array}{l}\text { Adjusted } \\
\mathrm{R}^{2}\end{array}$ & & $\mathrm{~F}$ & Sig. \\
\hline $\begin{array}{l}\text { a. Predictors: (Constant), Availability } \\
\text { of infrastructure }\end{array}$ & $.181^{\mathrm{a}}$ & .033 & .023 & & 3.327 & $.071^{\mathrm{b}}$ \\
\hline \multicolumn{7}{|l|}{ Coefficients } \\
\hline \multirow{2}{*}{$\begin{array}{l}\text { a. Dependent Variable: the waste- } \\
\text { sorting behavior }\end{array}$} & $\begin{array}{c}\text { Unstandardized } \\
\text { Coefficients }\end{array}$ & $\begin{array}{l}\text { Standardized } \\
\text { Coefficients }\end{array}$ & \multirow[t]{2}{*}{$\mathrm{T}$} & \multirow[t]{2}{*}{ Sig. } & \multicolumn{2}{|c|}{$\begin{array}{l}\text { Collinearity } \\
\text { Statistics }\end{array}$} \\
\hline & $\mathrm{B}$ & Beta & & & Tolerance & VIF \\
\hline \begin{tabular}{|l|l|} 
& (Constant) \\
\end{tabular} & 2.303 & & 6.795 & .000 & & \\
\hline $1^{1}$ Availability of infrastructure & .212 & .181 & 1.824 & .071 & 1.000 & 1.000 \\
\hline
\end{tabular}

The model (Table 4) shows the relationship between the availability of infrastructure and waste-sorting behavior is insignificant because it is greater than 0.05 . This could be attributed to the unavailability of infrastructure, which led most respondents (around 40\%) to choose "not applicable to the related statements." Thus, H2 is rejected.

4.7.3 H3: Perceived costs and benefits have a positive significant impact on behavioral intention for waste-sorting 
Table 5: Regression Model Output for H3

\begin{tabular}{|l|c|c|c|c|c|}
\hline Model Summary & $\mathrm{R}$ & $\mathrm{R}^{2}$ & $\begin{array}{c}\text { Adjusted } \\
\mathrm{R}^{2}\end{array}$ & $\mathrm{~F}$ & Sig. \\
\hline Model & $.071^{\mathrm{a}}$ & .005 & -.005 & .499 & $.482^{\mathrm{b}}$ \\
\hline $\begin{array}{l}\text { a. Predictors: } \\
\text { Constant), Perceived } \\
\text { costs and benefits }\end{array}$ & & & & & \\
\hline
\end{tabular}

\section{Coefficients $^{\mathrm{a}}$}

\begin{tabular}{|c|c|c|c|c|c|c|c|}
\hline \multirow{2}{*}{\multicolumn{2}{|c|}{$\begin{array}{l}\text { a. Dependent Variable: behavioral } \\
\text { intention }\end{array}$}} & \multirow{2}{*}{\begin{tabular}{|c}
$\begin{array}{c}\text { Unstandardizec } \\
\text { Coefficients }\end{array}$ \\
B
\end{tabular}} & \multirow{2}{*}{$\begin{array}{l}\text { Standardized } \\
\text { Coefficients } \\
\text { Beta }\end{array}$} & \multirow[t]{2}{*}{$\mathrm{T}$} & \multirow[t]{2}{*}{ Sig. } & \multicolumn{2}{|c|}{$\begin{array}{l}\text { Collinearity } \\
\text { Statistics }\end{array}$} \\
\hline & & & & & & Tolerance & VIF \\
\hline \multirow[b]{2}{*}{1} & (Constant) & 3.943 & & 10.843 & .000 & & \\
\hline & $\begin{array}{l}\text { Perceived costs } \\
\text { and benefits }\end{array}$ & .089 & .071 & .706 & .482 & 1.000 & 1.000 \\
\hline
\end{tabular}

The model (Table 5) shows an insignificant relationship (greater than 0.05) between the perceived costs/benefits and waste-sorting behavior. This could be attributed to the fact that the respondents in the chosen sample have been exposed to the awareness of wastesorting and are aware of the consequences of not recycling. Therefore, $\mathrm{H} 3$ is rejected.

\subsubsection{H4: Awareness of consequence has a positive significant impact on} behavioral intention for waste-sorting.

Table 6: Regression Model Output for $\mathrm{H} 4$

\begin{tabular}{|l|c|c|c|c|l|}
\hline Model Summary & $\mathrm{R}$ & $\mathrm{R}^{2}$ & $\begin{array}{c}\text { Adjusted } \\
\mathrm{R}^{2}\end{array}$ & $\mathrm{~F}$ & Sig. \\
\hline $\begin{array}{l}\text { Model } \\
\text { a. Predictors: (Constant), Awareness } \\
\text { of consequence }\end{array}$ & $.445^{\mathrm{a}}$ & .198 & .190 & 24.152 & $.000^{\mathrm{b}}$ \\
\hline
\end{tabular}

\section{Coefficients $^{\mathrm{a}}$}

\begin{tabular}{|c|c|c|c|c|c|c|}
\hline \multirow{2}{*}{$\begin{array}{l}\text { a. Dependent Variable: behavioral } \\
\text { intention }\end{array}$} & $\begin{array}{c}\text { Unstandardizec } \\
\text { Coefficients }\end{array}$ & $\begin{array}{c}\text { Standardized } \\
\text { Coefficients }\end{array}$ & \multirow[t]{2}{*}{$\mathrm{T}$} & \multirow[t]{2}{*}{ Sig. } & \multicolumn{2}{|c|}{$\begin{array}{c}\text { Collinearity } \\
\text { Statistics }\end{array}$} \\
\hline & $\mathrm{B}$ & Beta & & & Tolerance & VIF \\
\hline (Constant) & 1.815 & & 3.714 & .000 & & \\
\hline$1 \longdiv { \text { Awareness of conse } }$ & .546 & 445 & 4.915 & .000 & 1.000 & . .006 \\
\hline
\end{tabular}

The model (Table 6) shows a significant positive relationship (less than 0.05) between recycling skill and waste-sorting behavior. Every change by 100\% in the awareness of consequences will lead to a change in waste-sorting behavior by $54.6 \%$. Moreover, the $\mathrm{R}^{2}$ (0.198) shows that the awareness of consequence explains $19.8 \%$ of the waste-sorting behavior. Thus, $\mathrm{H} 4$ is not rejected.

4.7.5 H5: Perception of waste pickers has a negative significant impact on behavioral intention for waste-sorting.

Table 7: Regression Model Output for H5

\begin{tabular}{|l|c|c|c|c|l|}
\hline Model Summary & \multicolumn{3}{|c|}{ ANOVA $^{\mathbf{a}}$} \\
\hline Model & $\mathrm{R}$ & $\mathrm{R}^{2}$ & $\begin{array}{c}\text { Adjusted } \\
\mathrm{R}^{2}\end{array}$ & $\mathrm{~F}$ & Sig. \\
\hline $\begin{array}{l}\text { a. Predictors: (Constant), Perception } \\
\text { of waste pickers }\end{array}$ & $.002^{\mathrm{a}}$ & .000 & -.010 & .000 & $.986^{\mathrm{b}}$ \\
\hline
\end{tabular}


Coefficients $^{\mathrm{a}}$

\begin{tabular}{|l|l|c|c|c|c|c|c|}
\hline \multirow{2}{*}{$\begin{array}{l}\text { a. Dependent Variable: behavioral } \\
\text { intention }\end{array}$} & $\begin{array}{c}\text { Unstandardized } \\
\text { Coefficients }\end{array}$ & $\begin{array}{c}\text { Standardized } \\
\text { Coefficients }\end{array}$ & \multirow{2}{*}{$\mathrm{T}$} & \multirow{2}{*}{ Sig. } & \multicolumn{2}{|c|}{$\begin{array}{c}\text { Collinearity } \\
\text { Statistics }\end{array}$} \\
\cline { 3 - 9 } \cline { 5 - 8 } & B & Beta & & & Tolerance & VIF \\
\hline \multirow{2}{*}{1} & (Constant) & 4.188 & & 12.320 & .000 & & \\
\cline { 2 - 8 } & Perception of waste pickers & .002 & .002 & .017 & .986 & 1.000 & 1.000 \\
\hline
\end{tabular}

The model (Table 7) shows an insignificant relationship (greater than 0.05) between the perception of waste pickers and waste-sorting behavior. However, this finding needs to be investigated more when expanding the sample. Thereby, $\mathrm{H} 5$ is rejected.

\section{Conclusion and Recommendations}

Global perspectives have emerged because of the need for proactive environmental control management, to mitigate the damaging effects of industrial pollution and waste. Consequently, governments and nongovernmental organizations began promoting and implementing regulations and policies to slow and reverse the rapid destruction of natural resources and their negative effect on society. The importance of Green HRM is seen in the implementation of the design of the institution's infrastructure, from an environmentally friendly designed building to a series of Green Superstructure encompassing services aligned with the concept of sustainability, as a way to promote positive competitive environmental impact.

From a managerial perspective, the main conclusion arising is a culture shift towards the enhancement of more cultural agility practices within the university institution towards achieving Green HRM to sustain the policy of Solid Waste Management. It is a mindset change reinforced by a behavioral shift as Green HRM uses HRM policies and management practices to promote sustainable use of resources and prevent harm arising from environmental concerns within a business organization (Renwick, Redman, \& Maguire, 2013). In universities, Green HRM deals with environmental issues and also takes into consideration the development of economic and social wellbeing of humans in real life. GHRM helps to generate sustainable competitive advantage as environmental activities enhance organization performance, which is the main reason organizations became concerned in ecological issues stating that environmental protection is the best way to improve themselves among the surrounding competitive environment (Bhutto, S. A., \& Auranzeb (2016).

From a practical implication, the research conducted is paralleled in action with the 2030 strategy towards the stakeholders' involvement in society to engage in a dialog for sustainable development. Moreover, it will yield an intensive social impact and pave the way to more practices from other higher education institutions to transcend this behavior to their youth community. Practices are extended to a micro-level economic impact where the university involved in this strategy can earn revenues by selling its solid wastes to companies working in the field and willing to purchase. Alternatively, they can donate it to nonprofit organizations, which are considered a corporate social responsibility (CSR) tool toward citizens' involvement in the community. However, the limitations might include the risks in sustaining SWM in a private institution like organizational, financial 
risks, and resistance of biased members to accommodate new policies. In this study, the university is viewed as a business unit encompassing economic, business, and social environments that needs a tremendous effort to change its stakeholders' mindset in handling sustainability projects.

The researchers highlight the below policies as recommendations in alignment with the scholarly literature findings and with practical implications to increase students' awareness of SWM:

- Design a service blueprint for SWM within the campus which is reflecting on the internal environment management of the campus.

- Build capacities and train staff and students to increase their environmental customer cooperation.

- Outsource the collection of solid waste to recycling specialized companies which will facilitate the implementation of the eco design into practicing the solid waste management.

- Publish a sustainability report for the university to document its practices in this regard to highlight the cultural shift towards the NPM trends for increasing sustainability and enhance the citizen-enabled strategy of involvement.

- Analyze practices to face problems of waste streams at the root cause (upstream innovation) which is aligned with supply chain perspective and enhances efforts towards an environmentally friendly institution.

- Building on capacities, training, and information exchange around teams in the institution under study on SWM to increase customers' cooperation.

- Education and awareness about an agile operational framework to execute the SWM project balancing cost and benefit to the institution under study to maximize the practical implementation of solid waste management policy. This in turn will help in keeping the institution as a signatory to the United Nations Principles of Responsible Management in Education (PRME).

\section{References}

Ahi, P., \& Searcy, C. (2013). A comparative literature analysis of definitions for green and sustainable supply chain management. Journal of Cleaner Production, 52, 329-341.

Bennett, D., \& Nunes, B. (2008). A Green Operation framework and its application on automotive industry. Benchmarking: An International Journal, 17(3), 396-420.10.1142/9789812790545_0009.

Bhutto, S. A., \& Auranzeb, Z. (2016). Effects of green human resources management on firm performance: An empirical study on Pakistani firms. European Journal of Business and Management, 8(16), 119_ 125

Diefenbach, T. (2009). New public management in public sector organizations: The dark side of managerial enlightenment. Public Administration, 87(4), 892-909.

Dumitrescu Peculea, A. (2019). Performance in public administration: Doing outside the box under the rule of procedures. Theoretical and Applied Economics, 26(1), 151-158.

Fan, B., Yang, W., \& Shen, X. (2019). A comparison study of 'motivation-intention-behavior'model on household solid waste sorting in China and Singapore. Journal of Cleaner Production, 211, 442454.

Geng, R., Mansouri, S. A., \& Aktas, E. (2017). The relationship between green supply chain management and performance: A meta-analysis of empirical evidence in Asian emerging economies. International Journal of Production Economics, 183, 245-258. 
Griggs, D., Stafford-Smith, M., Gaffney, O., Rockström, J., Öhman, M. C., Shyamsundar, P., Steffen, W., Glaser, G., Kanie, N., \& Noble, I. (2013). Policy: Sustainable development goals for people and planet. Nature, 495(7441), 305-307.

Halligan, J., \& Bouckaert, G. (2008). Managing performance: International comparisons. Routledge.

Hamel, G., Doz, Y. L., \& Prahalad, C. K. (1989). Collaborate with your competitors and win. Harvard Business Review, 67(1), 133-139.

http://stats.oecd.org/glossary/detail.asp?ID=2508 (retrieved 12 April 2019).

http://www.desertec.org/concept/ "Clean power from the desert"”

https://www.igi-global.com/dictionary/customer-cooperation/71016 Published in IGI Global, publisher of timely knowledge. (retrieved 20 September 2020)

International Insitute of Administrative Sciences IIAS (2008) http://sustainabledevelopment.un.org/content /document/2013150612-Final-SDSN-indicator-Report1.

Kairouz, A., Hokayem, J. E., \& Hage, U. E. (2016). Sustainability of public management in the developing countries: The case of Lebanon. Procedia - Social and Behavioral Sciences, 221, 378-387.

Klassen, R. D., \& Vereecke, A. (2012). Social issues in supply chains: Capabilities link responsibility, risk (opportunity), and performance. International Journal of Production Economics, 140(1), 103-115.

Lai, K. H., Wong, C. W. Y., \& Lam, J. S. L. (2015). Sharing environmental management information with supply chain partners and the performance contingencies on environmental munificence. International Journal of Production Economics, 164, 445-453.

Norton, M. (2012). Sustainability: Duty or opportunity for business? Routledge.

O'Brien, M. (2013). Consumers, waste and the 'throwaway society' thesis: Some observations of the evidence. International Journal of Applied Sociology, 3(2), 19-27.

OECD - Organization for Economic Co-Operation and Development (2003). Glossary of statistical terms: Solid waste.

Ormanidhi, O., \& Stringa, O. (2008). Porter's model of generic competitive strategies. Business Economics, 43(3), 55-64.

Ramayah, T., Lee, J. W. C., \& Lim, S. (2012). Sustaining the environment through recycling: An empirical study. Journal of Environmental Management, 102, 141-147.

Renwick, D. W. S., Redman, T., \& Maguire, S. (2013). Green human resource management: A review and research agenda. International Journal of Management Reviews, 15(1), 1-14.

Sachs, J. D. (2012). From millennium development goals to sustainable development goals. The Lancet, 379(9832), 2206-2211.

Sroufe, R. (2003). Effects of environmental management systems on environmental management practices and operations. Production and Operations Management, 12(3), 416-431.

Stern, P. C., Dietz, T., Abel, T., Guagnano, G. A., \& Kalof, L. (1999). A value-belief-norm theory of support for social movements: The case of environmentalism. Human Ecology Review, 81-97.

Thøgersen, J., \& Ølander, C. F. (1995). Perceptions of waste and recycling. A qualitative analysis. In The 20th Annual Colloquium of IAREP, The International Association for Research in Economic Psychology August 1995 Frontiers in Economic Psychology Norwegian School of Economics and Business Administration. Bergen, August.

, M., Phillips, P. S., \& Read, A. D. (2004). Using the theory of planned behaviour to investigate the determinants of recycling behaviour: A case study from Brixworth, UK. Resources, Conservation and Recycling, 41(3), 191-214.

Uddin, M. M., \& Islam, R. (2015). Green HRM: Goal attainment through environmental sustainability. Journal of Nepalese Business Studies, 9(1), 14-19.

Valentin, A., \& Spangenberg, J. H. (2000). A guide to community sustainability indicators. Environmental Impact Assessment Review, 20(3), 381-392.

Wang, Y., \& Lu, Y. S. (2001). Factors promoting municipal solid waste sorting collection. Environ. San. Eng., 9, 190-192.

Zhu, Q., \& Sarkis, J. (2004). Relationships between operational practices and performance among early adopters of green supply chain management practices in Chinese manufacturing enterprises. Journal of Operations Management, 22(3), 265-289.

Zhu, Q., Sarkis, J., \& Lai, K. H. (2008). Confirmation of a measurement model for green supply chain management practices implementation. International Journal of Production Economics, 111(2), $261-273$. 


\section{Appendix 1: Authors' Biographies}

Dr. Zeinab Shawky Younis, BA. Mass Communication 1994, MS. of P.A. 1998, PhD 2009, Associate Professor 2017. Currently an Associate Professor of Public Administration, and head of the international aspect committee at the Business department, at the Faculty of Business Administration, Economics and Political Science, The British University in Egypt. Since February, 2016-now she was appointed as the Director of the Research Center for Innovation, Governance and Green Economy and has been an elected Member of the Senate Committee at the level of the faculty. Formerly, The head of General Business Specialization and Community services coordinator, Business department.

Dr. Ola Mamdouh is currently working as a lecturer at the British University in Egypt. She got her $\mathrm{PhD}$ in the area of sustainable supply chain management in Ain Shams University. She got her master's degree in business administration - production and operations management - from Ain Shams University. Her main interest and research field is operations management, supply chain management, sustainable development and project management. 